\title{
Theatricalization of Politics: Aspects of Politics in Media Scenes - Introduction
}

\author{
Christiana Constantopoulou \\ ORCID: 0000-0002-8648-4995 \\ Panteion University of Social and Political Sciences \\ School of Social Sciences, Athens
}

Received 31 October $2017 \cdot$ Revised 10 November $2017 \cdot$ Accepted 22 November 2017

\section{Abstract}

Theatricalization is an important aspect of social life in general, of political life in particular. Aspects of the political scene and action are given in mass and new media discourse as well as in mass cultural productions (as "narratives" of the contemporary reality). Given that people understand reality first of all on the symbolic level, the analysis of these narratives is an ideal approach of the meaning given to politics and communication nowadays: images of the economic crisis, of the migrants and/or refugees, of identities (given by media discourse or by mass cultural productions), constitute a basic imprint of the expressions of the current "social myths". We emphasize on the concept of theatricalization as a constitutive social (and political) symbolism and on the importance of theatricalization in the contemporary communication. Because diverse narratives symbolize our reality, we focus on particular contemporary social myths; myths may be not real but they influence reality because they symbolize it (they explain it, they justify it and eventually they could make it change). In this sense, we consider this thematic volume as quite revealing for the contemporary communicational trends and for the contemporary (globalized) society.

Keywords: presentation, social representations, social myths, narratives, symbolization, communication, media.

Theatricalization is (and has always been) an important aspect of social life in general, of political life in particular.

First of all we should clarify the choice of the term "theatricalization" used in this thematic edition: it is understood in the sense given by E. Goffman (1959) to "presentation" (better attributed by the French term Mise en Scène). This choice was done in order to emphasize the particular aspect of political communication which is associated to its symbolic appearance and presentation; given the fact that in media everything is primarily "representation" anyway it was meant in order to avoid the current confusion due to the importance of media representations nowadays. We also would like to mark out the importance of social representations (those dominant "images" which define the frame in which reality is understood).

(C) Authors. Terms and conditions of Creative Commons Attribution 4.0 International (CC BY 4.0) apply. Correspondence: Christiana Constantopoulou, Panteion University, Sygrou 136, 17671 Athens. E-mail: christiana.constantopoulou@panteion.gr. 


\section{Theatricalization as constitutive social (and political) symbolism}

"Presentation" is a major social feature in everyday life ${ }^{1}$ and becomes a parameter of an utmost importance in "political life" (from Royal Sacraments to Electoral Campaigns). Depending on specific societies and on historical conjuncture political "staging" (theatricalization), is supposed to impress, reassure, mystify or terrify the audience, indicating the different responsibilities of a government, trying to give advantage to a political frame or personality (including misinformation - just like propaganda does).

Closely linked to this "theatricalization" is the issue of "legitimacy" of power (emphasizing the appearance and using techniques similar to the techniques of "theater" - of spectacle in general). Some "kinds of theatricalization" continue for many years (such as Royal Sacraments) while some others are only a fashion (such as the contemporary fashion of presentation of a politician's private life). The role of different technologies (printing, photography, cinema, television or internet) may be different as far as it concerns the degree of control that authorities possess on their "image" (they give possibilities and at the same time may surpass one person's or one party's control).

The necessity to "show" a democratic "front" characterizes most of the modern republic states imposing an appearance of "simplicity" accompanying political actors' life (even the presence of those working on the leaders' personal security, as body guards, is meant to be "discreet", at least in most cases, in order to "present" the leader's not exceptional existence in everyday life: appearing familiar is thought as a very good feature of a political profile).

Thus by "political theatricalization" we understand a kind of practice of the "professional politics" asking for popularity and influence on the public (practice which nowadays is realized in terms and conditions of the mass media representations). The politician is confronted to the problem of a convincing staging of authority, diligence, principles fidelity, competence, and of every political characteristic positively connoted, which make other people believe to him/her ${ }^{2}$ and consider him/her as the best solution possible. According to Machiavelli's theory a politician ought to present an image which will help him (and nowadays "her") to access to the government; to succeed as political person means not to have illusions but on the contrary be able to give illusions to the audience (see Ronald Hitzler, 2014).

Consequently, in order to understand the relation between symbols and reality, we must analyze the "presentation" (and the "illusions" it contains which are important for the audience). We could then better understand the political symbols, dynamics and rituals in the frame of the global context (Abélès, 1990), if we followed the "anthropological" point of view.

\footnotetext{
${ }^{1}$ As indicated by E. Goffman (1959): in this famous book, Goffman describes the theatrical performances that occur in face-to-face interactions He holds that when an individual comes in contact with another person, he attempts to control or guide the impression that the other person will form of him, by altering his own setting, appearance and manner. At the same time, the person that the individual is interacting with attempts to form an impression of, and obtain information about, the individual. Goffman also believes that participants in social interactions engage in certain practices to avoid embarrassing themselves or others. Society is not homogeneous; we must act differently in different settings; this recognition led Goffman to his dramaturgical analysis. He saw a connection between the kinds of "acts" that people put on in their daily lives and theatrical performances. In a social interaction, as in a theatrical performance, there is an onstage area where actors (individuals) appear before the audience; this is where positive self-concepts and desired impressions are offered. But there is, as well, a backstage - a hidden, private area where individuals can be themselves and drop their societal roles and identities.
}

${ }^{2}$ Nowadays there are women in politics, although their percentage is very low. 
In this sense, we believe that it is relevant to refer to Bourdieu's analysis of the meaning of a very important practice, the practice of the "rites of passage", as defined by Arnold Van Gennep (Bourdieu, 1982). What does the rite of passage separate? A "before" and an "after" - he gives as example the "ritual/act" of circumcision - or in other words, those the rite concerns and those it does not (in the example of circumcision men are concerned but women are not). In the crossing of the line, should one consider most important the "crossing" (as the "rite of passage" implies), or on the contrary the line itself? We understand the arbitrary limit which the rite of institution (in the active sense of "instituting") consecrates and legitimates.

It is thus understood, how the instituting rite, an act of "social magic", owes its symbolic efficacy to the fact that it signifies to a man what he is and what he has to be. The work of institution is a process of inculcation which treats the body as a memory so as to induce a second nature which is the social function of "nature".

In the same way, the rite consecrates a "difference" approved by the institution symbolically (this is the difference between a "leader" and the "others") and includes coded behaviors; but this "representation" obliges also the "leader" to adopt a certain behavior as well, in order to be conform to the "idea". In other words there exists a common belief to which people in a given context are conform (in this sense Goffmann, 1959, also explains the importance of the conformation to the codes and symbols necessary for existing in a given society).

The symbolical work is complicated including several practices in the public sphere, such as the games of antagonistic or not relations among groups. We should then understand "rites" (symbols represented) as constitutive of the political space, as anthropologists use to do. Thus we can understand the major relationship among symbolization, representation and interpretation of reality (and of political reality of course): although "staging" is thought to contain some kind of "lie" 3 it also indicates some primary elements of symbolization (absolutely necessary in order to understand a society and be able to act in it); it so happens also in the contemporary (political) world.

\section{Theatricalization in contemporary communication}

Although theatricalization was always important in social life, it seems particularly dominant nowadays because of three supplementary characteristics: (1) the importance of image in the so called "spectacle society" (2) the supremacy of some theoretical trends (such as behaviorism and systemic analysis in communication theory); (3) the transition from the Freudian to the Communicational Culture.

1) The Society of the Spectacle refers the well-known work of Guy Debord (1967), who traces the development of a modern society in which authentic social life has been replaced with its representation: "All that once was directly lived has become mere representation". Debord argues that the history of social life can be understood as "the decline of being into having, and having into merely appearing”. This condition, according to Debord, is the "historical moment at which the commodity completes its colonization of social life”.

The spectacle is the inverted image of society in which relations between commodities have supplanted relations between people. "The spectacle is a social relationship between people

3 Given the vulgar meaning of the word "hypocrite" which in theatrical terms (ancient Greek drama) only means the person who replies in a dialogue. 
that is mediated by images". We could add here that in this context, the "onstage" area (as explained by Goffman) takes much more importance, given the fusion between the "public" and the "private" sphere in the so called "social media".

In his analysis of the spectacular society, Debord notes that quality of life is impoverished because of the lack of authenticity; human perceptions are affected, and there's also a degradation of knowledge, with the hindering of critical thought. Debord analyzes the use of knowledge to assuage reality: the spectacle obfuscates the past, imploding it with the future into an undifferentiated mass in a kind of never-ending present; in this way the spectacle prevents individuals from realizing that the society of spectacle is only a moment in history.

2) Some theoretical trends (still dominant in communication studies) advantage the overvalue of the "surface" (the outside visible features of phenomena becoming synonyms of "objective reality") disadvantaging the importance of "subjectivities" of what was initially called behavioral "black box" (emotional or sentimental "intelligence"); behaviorism for instance (and the systemic analysis) treats all psychological phenomena in terms of stimuli, responses, and stimulus-response associations (Watson launched the system in 1913, with his behavioristic manifesto). The human mind is given like a black box: It's sealed, closed, and inaccessible and you can't see inside. To Watson, what goes on in the box is unimportant and psychological states can be explained by reference to the objective and observable components of behavior. Early mass communication theorists, who saw the media as providing external stimuli that caused immediate responses, frequently used behaviorist notions. Although pure behaviorism is no more dominant in communication theories, it seems that the contemporary communicational trends do stay very much on the surface of the communicational process (they stay much more on the external contemporary cultural characteristics such as for example the "Selfie attitude" and the "look culture", the extreme simplification of messages which are in general understood in terms of mostly surficial analyses4): so the "appearance" seems to become the most important communicational element and thus, theatricalization - or the formal moment of a communication procedure - becomes more "central" than ever or elsewhere.

We would also like to remind Sherry Turkle's first worldwide known book "The second self, computers and the human spirit" (1985). In brief, what was exposed there, concerns the contemporary socialization in a world where computers are dominant: young adolescents (at the age of socialization) learn to consider the "other" as their own reflection due to computer mediation. This would represent a transition from the Freudian Culture (where one's self had reaction with the others) to the contemporary "Communicational" Culture (where communication is computer mediated and becomes in reality communication with one's own self: the "other" conversing with us, being the supremacy of the self5) conducing to what Lucien Sfez (Critique de

\footnotetext{
${ }^{4}$ There are of course opposite (and critical) theories (ex. authors like Philippe Breton, 1990, 1997, 2000, or Lucien Sfez, 1990, 1991) which in the flow of media studies seem rather "marginal" (they are not translated in English!).

5 In The Second Self, Sherry Turkle looks at the computer not as a "tool", but as part of our social and psychological lives; she looks beyond how we use computer games and spreadsheets to explore how the computer affects our awareness of ourselves, of one another, and of our relationship with the world. "Technology", she writes, "catalyzes changes not only in what we do but in how we think". Turkle talks to children, college students, engineers, scientists, hackers, and personal computer owners - people confronting machines that seem to think and at the same time suggest a new way for us to think - about human thought, emotion, memory, and understanding. Her interviews reveal that we experience computers as being on the border between inanimate and animate, as both an extension of the self and part of the external world. Their special place betwixt and between traditional categories is part of what makes them
} 
la Communication, 1993) had named "autistic society" (this kind of "communication" tending to become dominant nowadays). Of course this trend, favors to consider "presentation" as the utmost characteristic of nowadays (giving to it a bigger symbolic importance for the contemporary mentality very much universalized - because of the importance of media in the everyday life but also because of the international political and economic system implying the so called "globalization").

\section{Contemporary media narratives: symbolizing our reality}

If we keep in mind the above three characteristics, we understand that the "show" becomes even more important and that consequently, this affects the contemporary "narration" of reality (on "identities", on "borders", on "human rights" and on "possibilities").

In this way, important aspects of the political scene and action are given in mass media discourse and in the so called "new, or social media discourse, as well as in mass cultural productions (mainly cinema and TV series) as "narratives" of the contemporary social and political reality. Because people understand reality first of all on the symbolic level, the analysis of these narratives is an ideal approach of political communication nowadays: not only as far as it concerns governmental and state (namely political) affairs but also as far as it concerns ideas and attitudes which sustain the contemporary formation and/or perpetuation of diverse powers. Images of the economic crisis, of the migrants and/or refugees, of diverse identities (as framed by media discourse or by mass cultural productions) constitute a basic imprint of the contemporary "social myths".

Some aspects of these contemporary myths are analyzed in this volume; more specifically there is: an analysis concerning the reporting of the Crimea War, an approach of cultural journalism and the representations of the crisis in culture; a study of the representation of relational power in a successful TV serial, and an essay on the meanings of visual narratives nowadays. We think that this concerns an interesting approach of the contemporary "political" representations (including elements of the contemporary agenda but also symbolisms proposed by fictional discourse to the big audience). All the approaches are focusing on contemporary social myths: myths may be not real but they influence reality because they symbolize it (they explain it, they justify it and eventually they could make it change). In this sense, we consider this thematic volume as quite revealing for the contemporary communicational trends and for the contemporary (globalized) society.

compelling and evocative. Why we think of the workings of a machine in psychological terms - how this happens, and what it means for all of us is the fascinating subject of The Second Self. 
Ch. Constantopoulou - Theatricalization of Politics: Aspects of Politics in Media Scenes - Introduction

\section{References}

Abélès, M. (1990). Mises en scène et rituels politiques: une approche critique, in Hermès, CNRS-Éditions (pp. 241-259), HAL Id: hal-00493561 https://hal.archives-ouvertes.fr/hal-00493561.

Bourdieu, P. (1982). Les rites comme actes d'institution. Actes de la Recherche en Sciences Sociales, 43(1), $58-63$.

Breton, Ph. (1990). Une histoire de l'informatique. Paris: Livre de Poche.

... , (1997). L'utopie de la communication: le mythe du village planétaire. Paris: Livre de Poche.

... , (2000). Le culte de l'internet: Une menace pour le lien social? Paris: La Découverte.

Christin, P., Goetzinger, A., \& Sfez, L. (1991). Le message du Simple. Paris: Seuil.

Debord, G. (1967). La société du spectacle. Paris: Gallimard.

Goffman, E. (1959). The presentation of self in everyday life. University of Edinburgh Social Sciences Research Centre, Anchor Books edition.

Hitzler, R. (2014). Mise en scène et représentation de la politique aujourd'hui, Trivium, 16, accessed on 31 October 2016 (pp. 1-16). URL: http://trivium.revues.org/4776/.

Sfez, L. (1990), Critique de la communication. Paris: Seuil.

Turkle, Sh. (1984). The second self, computers and the human spirit. Massachusetts: MIT Press.

Van Gennep, A. (1981). Les rites de passage. Paris: E. Nourry (first edition 1909). 